ISSN : 2303-1514 | E-ISSN : 2598-5949

\title{
TEACHERS' PERFORMANCE IN INSTILLING DISCIPLINARY CHARACTER FOR GRADE IV STUDENTS
}

\author{
Felensky Nurberlian $^{1}$, M. Hosnan ${ }^{2}$, Rina Yuliana ${ }^{3}$ \\ ${ }^{1,2,3}$ Jurusan Pendidikan Guru Sekolah Dasar, Universitas Sultan Ageng Tirtayasa, Banten, Indonesia \\ felenskynb99@gmail.com ${ }^{1}{ }^{2}$ rinayuliana@untirta.ac.id ${ }^{3}$
}

\section{KINERJA GURU DALAM MENANAMKAN KARAKTER DISIPLIN SISWA KELAS IV}

\begin{abstract}
ARTICLE HISTORY
ABSTRACT

Abstract: This study aimed to describe the planning process for embedding the disciplinary character in students and to describe the process of embedding disciplinary character in students as well as the results of embedding the disciplinary character at SDN Banjarsari 5 Serang. The method of this research was descriptive qualitative which was through data reduction, data presentation, and drawing conclusions or verification. This research was conducted by triangulating data such as interviews and observations. The result of interviews found that the teacher implemented the process of embedding the disciplinary characters in

Submitted: students during the learning process at grade IV. Then, based on observations regarding the process of embedding student discipline character, it was concluded that the teacher implemented the disciplinary character in students while the results of the interviews with teachers and the student observations concluded that students had a good impact by achieving the goal of knowing the teacher's performance in instilling students' discipline character.

Keywords: teacher performance, discipline character, students

Accepted:

02 Agustus 2021

$02^{\text {th }}$ August 2021

Published:

27 Agustus 2021

$27^{\text {th }}$ August 2021

Abstrak: Penelitian ini bertujuan untuk mendeskripsikan proses perencanaan penanaman karakter disiplin pada siswa dan untuk menggambarkan proses pelaksanaan penanaman karakter disiplin pada siswa serta untuk menggambarkan hasil dari penanaman karakter disiplin siswa di SDN Banjarsari 5 Kota Serang. Metode penelitian yang digunakan adalah metode kualitatif deskriptif yaitu dengan cara reduksi data, penyajian data, dan penarikan kesimpulan atau verifikasi. Penelitian ini dilakukan triangulasi data seperti wawancara dan pengamatan. Berdasarkan penelitian yang telah dilakukan melalui wawancara bahwa guru melaksanakan terkait perencanaan penanaman karakter disiplin pada siswa dalam pelaksanaan proses pembelajaran di kelas IV. Kemudian berdasarkan observasi mengenai proses pelaksanaan penanaman karakter disiplin siswa dapat disimpulkan bahwa guru melaksanakan penanaman karakter disiplin kepada siswa, serta hasil dari wawancara guru dan observasi siswa dapat disimpulkan bahwa siswa memiliki dampak baik dengan tercapainya tujuan untuk mengetahui kinerja guru dalam menanamkan karakter disiplin siswa.

Kata Kunci: kinerja guru, karakter disiplin, siswa

\section{CITATION}

Nurberlian, F., Hosnan, M., \& Yuliana, R. (2021). Teachers' Performance in Instilling

Disciplinary Character for Grade IV Students. Primary: Jurnal Pendidikan Guru Sekolah Dasar, 10 (4), 883-891. DOI: http://dx.doi.org/10.33578/jpfkip.v10i4.8139

\section{PENDAHULUAN}

Pendidikan adalah hal pokok yang akan menopang kemajuan suatu bangsa. Kemajuan suatu bangsa dapat diukur dari kualitas dan sistem pendidikan yang ada. Tanpa pendidikan, suatu negara akan tertinggal dengan negara lain. Pendidikan bermutu adalah pendidikan yang mampu mengembangkan potensi-potensi positif yang terpendam dalam diri peseta didik. Pendidikan akan menghasilkan tenaga-tenaga muda potensial yang tangguh dan siap bersaing 
dalam masyarakat dunia dan melahirkan penerus bangsa yang cerdas dan kompeten sehingga kondisi bangsa akan terus mengalami perbaikan. Banyak realita di lapangan yang menunjukan bahwa kualitas manusia Indonesia sebagai sumber daya yang potensial masih jauh dari harapan. Hal ini terjadi akibat rendahnya kualitas pendidikan di Indonesia.

Pemerintah selalu berupaya untuk meningkatkan mutu pendidikan melalui berbagai kebijakan, antara lain sertifikasi guru dan dosen, bantuan operasional sekolah, pemberian block grant dan menetapkan standar nasional yang dituangan dalam Peraturan Pemerintah Nomor 19 Tahun 2005 Tentang Standar Nasional Pendidikan. Standar nasional pendidikan meliputi standar isi, proses, ketenagaan, sarana dan prasarana, pengelolaan, evaluasi, pembiayaan dan kompetensi lulusan. Dengan adanya standar nasional tersebut, maka arah peningkatan mutu pendidikan Indonesia menjadi lebih jelas. Apabila setiap satuan pendidikan telah dapat mencapai atau melebihi standar nasional pendidikan tersebut, maka kualitas satuan pendidikan dapat dinyatakan tinggi. Penyebab rendahnya mutu pendidikan di indonesia antara lain adalah masalah efektivitas, efisiensi dan standarisasi pengajaran, kurang kreatifnya para pendidik dalam membimbing peserta didik. Hal tersebut masih menjadi masalah pendidikan di indonesia pada umumnya.

Sistem pendidikan terdapat berbagai macam stakeholder yang saling berkaitan. Komponen yang paling urgen adalah pendidik. Pendidik memainkan peran yang sangat penting yang berdampak pada kualitas pendidikan yang dijalankan, maka perlu kiranya untuk melakukan pembinaan atau pengembangan yang profesional bagi guru, sehingga guru mampu menjalankan perannya secara efektif. Untuk mewujudkan tujuan tersebut, pendidikan harus mampu menciptakan sumber daya manusia berkualitas dan profesional sesuai dengan tujuan pendidikan. Oleh sebab itu, pendidikan harus dikelola secara profesional oleh tenaga yang profesional juga. Dalam usaha meningkatkan kualitas sumber daya pendidikan, guru merupakan sumber daya yang perlu dibina dan dikembangkan kemampuannya secara terusmenerus untuk menghasilkan kinerja yang baik, karena bagaimana untuk mencapai tujuan pendidikan, apabila tidak didukung dengan kualitas kerja yang baik. Kinerja guru (teacher performance) dapat diartikan sebagai hasil kerja yang dicapai oleh seorang guru disuatu lembaga pendidikan sesuai dengan tugas dan tanggung jawab dalam mencapai tujuan pendidikan.

Di abad ke-21, pendidikan bukan hanya terpaku dalam faktor intelektual yang dimiliki seseorang saat menempuh pendidikan namun juga harus diintegrasikan dengan faktor lain seperti halnya sikap, perilaku, dan karakter. Masalah pendidikan di Indonesia sangatlah kompleks karena di semua aspeknya terdapat persoalan yang perlu diselesaikan. Dekadensi moral telah merajalela dalam dunia pendidikan sehingga menjadi potret buram dalam dunia pendidikan. Hal ini bisa dilihat dari maraknya perkelahian antar pelajar, banyaknya kasus narkoba yang menjerat peserta didik, kurangnya sikap hormat kepada orang yang sudah dewasa, kasus mencontek yang sudah menjadi suatu kebiasaan, dan juga kedisiplinan yang masih sulit untuk siswa lakukan seperti terlambat datang kesekolah, mengerjakan tugas rumah di sekolah dan sebagainya. Alex Agboola dalam jurnal yang berjudul Bring Character Education Into Classroom (2012:168) menyatakan bahwa kebijakan pendidikan harus mengambil inisiatif untuk mengaktualisasikan pendidikan moral dalam sistem sekolah. Dilakukan bersama-sama, orang tua, guru, dan administrator sebagai pemangku kepentingan, harus bersama-sama bergabung untuk mendorong para peserta didik mewujudkan nilai-nilai karakter baik dalam hidup mereka, untuk itulah perlu penerapan pendidikan karakter di sekolah sehingga pembentukan karakter tidak hanya dipupuk dari keluarga tetapi juga di bina di sekolah.

Karakter merupakan hal yang sangat penting dalam berbangsa dan bernegara, oleh sebab itu hilangnya karakter akan menyebabkan hilangnya generasi penerus 
bangsa. Karakter juga memiliki fungsi sebagai penguat bangsa agar tidak mudah terombangambing. Karakter tidak datang dengan sendirinya, namun harus di bentuk dan di tanamkan untuk menjadikan bangsa yang bermartabat. Oleh karena itu, karakter harus diwujudkan secara nyata melalui tahapantahapan tertentu. Salah satu tahapan yang dapat dilakukan yaitu membangun dan mengembangkan karakter melalui pendidikan guna membuat bangsa ini memiliki karakter yang kuat. Karakter yang kuat adalah sandangan fundamental yang memberikan kemampuan kepada populasi manusia untuk hidup bersama dalam kedamaian serta membentuk dunia yang dipenuhi dengan kebaikan dan kebijakan, yang bebas dari kekerasan dan tindakan-tindakan tidak bermoral.

Ketaatan anak dalam menjalankan tata tertib sekolah merupakan suatu kesatuan yang dapat mengakibatkan suatu pembentukan sikap dan kepribadian peserta didik itu sendiri. Oleh karena itu, ketaatan dalam menjalankan tata tertib sekolah bagi peserta didik sangatlah penting. Tata tertib yang dimaksud sebagai rambu-rambu bagi siswa dalam bersikap, mengucap, bertindak dan melaksanakan kegiatan-kegiatan sehari-sehari di sekolah dalam menciptakan iklim dan kultur sekolah yang menunjang kegiatan pembelajaran yang efektif. Tetapi masih banyak sekali peserta didik yang masih melanggar tata tertib sekolah seperti terlambat datang kesekolah, tidak menggunakan atribut saat upacara, mengumpulkan PR tidak tepat waktu, dan lain sebagainya. Itu semua akan menjadi suatu kebiasaan yang buruk jika guru tidak memberikan hukuman yang berat bagi peserta didik yang melanggar peraturan.

Guru sebagai seorang manajer kelas dituntut untuk memiliki keterampilan dalam membina kedisiplinan peserta didik. Dalam membina kedisiplinan pada peserta didik di dalam lingkup sekolah, guru memiliki peran untuk mengarahkan apa yang baik bagi peserta didik, menjadi teladan dan memiliki perhatian penuh terhadap peserta didik. Kedisiplinan akan terwujud jika kinerja guru dalam hal pengajarannya sesuai dengan standar yang berlaku di sekolah, sehingga dapat menjadi pedoman peserta didik. Guru harus mampu menanamkan nilai-nilai kedisiplinan bagi peserta didik, terutama kedisiplinan bagi dirinya sendiri dan menghilangkan kebiasaan peserta didik dari tindakan yang menimbulkan masalah tentang kedisiplinan. Hal tersebut perlu dilakukan guru agar terhindar dari perilaku peserta didik yang tidak disiplin atau melanggar tata tertib sekolah yang telah ditetapkan.

Berdasarkan pengamatan saat berada di SDN Banjarsari 5 Kota Serang adalah ketika para peserta didik sudah melakukan kedisiplinan yang bagus di lingkungan sekolah seperti datang ke sekolah dengan tepat waktu, menjaga kebersihan lingkungan sekolah, tertib melaksanakan upacara, tertib memakai seragam sekolah dengan tepat. Begitupun kedisiplinan peserta didik juga sudah terbentuk saat akan memasuki kelas yaitu membuka sepatu dan di simpan dengan rapih agar kelas tidak kotor dan saat berada di dalam kelas pemimpin kelas memimpin doa lebih dahulu sebelum pembelajaran di mulai, memperhatikan guru saat sedang menerangkan, mengerjakan tugas dengan waktu yang sudah di tentukan oleh guru dan juga mengumpulakan PR dengan tepat waktu, sampai pembelajaran pun selesai peserta didik disiplin dalam melaksanakan piket kelas dan tertib membuang sampah pada tempatnya. Terbentuknya kedisiplinan tersebut tentunya adanya kinerja guru yang bagus serta memberi contoh kepada peserta didiknya untuk melakukan kegiatan disiplin.

\section{KAJIAN TEORI}

Menurut Sulistyorini (2001) yang dirangkum kembali dalam buku Suherman dan Saondi (2012:20) kinerja adalah tingkat keberhasilan seseorang atau kelompok orang dalam melaksanakan tugas dan tanggung jawabnya serta kemampuan untuk mencapai tujuan dan standar yang telah ditetapkan.

Lickona

dalam

Samani\&Hariyanto (2016:44) mendefinisikan pendidikan karakter sebagai upaya yang 
dirancang secara sengaja untuk memperbaiki karakter para peserta didik.

Disiplin adalah sikap dan tindakan seseorang menunjukan perilaku tertib terhadap peraturan yang ada (Yaumi, 2014:92). Dalam perspektif psikologis, peserta didik adalah individu yang sedang berada dalam proses pertumbuhan dan perkembangan, baik fisik maupun psikis menurut fitrahnya masingmasing. Sebagai individu yang tengah tumbuh dan berkembang, peserta didik memerlukan bimbingan dan pengarahan yang konsisten menuju ke arah titik optimal kemampuan fitrahnya (Arifin, 1996) dalam (Desmita, 2014:39)

\section{METODE PENELITIAN}

Penelitian bertempat di SDN Banjarsari 5 Kota Serang yang beralamat di Perum. Permata Banjar Asri-Cipocok Jaya, kota Serang. Tahun ajaran 2019-2020. Peneliti menggunakan deskriptif kualitatif sebagai metode penelitian yang digunakan. Metode tersebut bertujuan untuk memperoleh gambaran peristiwa atau fenomena yang terjadi. Penggalian data secara kualitatif memudahkan peneliti mendapatkan informasi yang luas sehingga memperkaya penemuan dalam analisa. Fokus utama penelitian yaitu proses perencanaan penanaman karakter, proses pelaksanaan penanaman karakter dan hasil dari penanaman karakter disiplin siswa kelas 4.

Pengolahan data penelitian selalu melibatkan proses analisis. Peneliti menganalisa data secara sistematis dan beriringan dengan proses pengumpulan data. Peneliti menggunakan analisa data dari Miles and Huberman, yang telah dikutip oleh Sugiyono (2014:246)

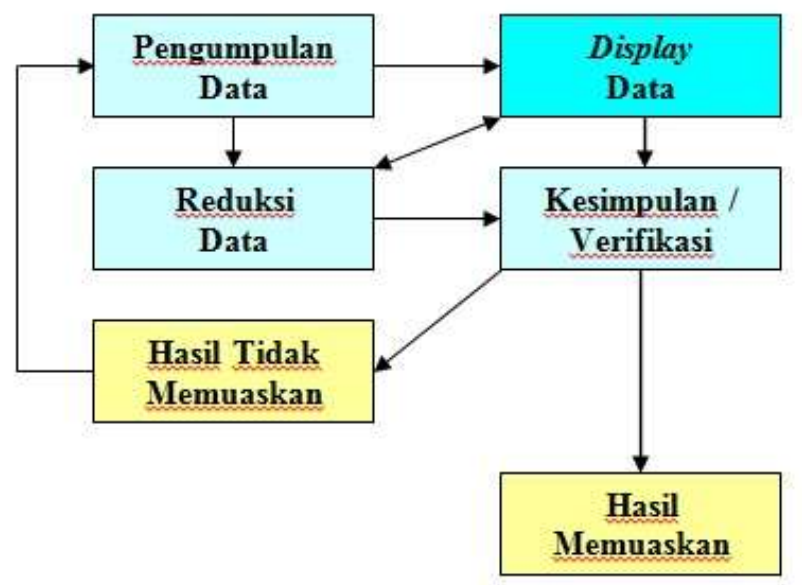

Gambar 1. Alur Penelitian

\section{HASIL DAN PEMBAHASAN}

Pada pembahasan mengenai kinerja guru dalam menanamkan karakter disiplin siswa kelas IV memiliki tujuan khusus yaitu:

1. Mengetahui proses perencanaan penanaman karakter disiplin pada peserta didik kelas

2. Mengetahui proses pelaksaanan penanaman karakter disiplin pada peserta didik kelas
3. Mengetahui hasil dari penanaman karakter disiplin pada peserta didik kelas 4

Sebelum menyusun pembahasan ini peneliti sudah melakukan analisis instrument wawancara dan observasi penelitian. Analisis instrument wawancara digunakan untuk mendapatkan informasi sejauh mana kinerja guru dalam menanamkan karakter disiplin peserta didik, sedangkan observasi digunakan untuk melihat langsung bagaimana proses perencanaan penanaman karakter disiplin 
kepada peserta didik, proses pelaksanaan, dan hasil dari penanaman karakter disiplin peserta didik di SDN Banjarsari 5 kota Serang.

\section{Proses Perencanaan Penanaman Karakter Disiplin pada Peserta Didik Kelas 4}

Setelah dilaksanakannya pengumpulan data seperti wawancara, observasi dan dokumentasi pada rumusan masalah ini diketahui proses perencanaan penanaman karakter disiplin yang terdapat di sekolah sudah baik, hal ini dikarenakan kinerja guru disana berjalan dengan baik dalam menanamkan karakter disiplin pada peserta didik. Adapun kinerja guru yang berjalan dengan baik sehingga dapat menanamkan karakter disiplin adalah dengan indikator sebagai berikut:

Menilai kualitas kinerja dapat ditinjau dari beberapa indikator yang meliputi:

a) Unjuk kerja

b) Penguasaan materi

c) Penguasaan profesional keguruan dan pendidikan

d) Penguasaan cara-cara penyesuaian diri

e) Kepribadian untuk melaksanakan tugasnya dengan baik (Sulistyorini, 2001)

Dari uraian di atas dapat disimpulkan indikator kinerja guru antara lain:

a) Kemampuan membuat perencanaan dan persiapan mengajar.

b) Penguasaan materi yang akan diajarkan kepada siswa.

c) Penguasaan metode dan strategi mengajar.

d) Kemampuan mengelola kelas.

e) Kemampuan melakukan penilaian dan evaluasi.

Dari penjelasan diatas maka dapat disimpulkan bahwa kinerja guru sangat berpengaruh dalam menanamkan karakter disiplin kepada peserta didik.

\section{Mempersiapkan Rpp}

Kinerja guru dalam menanamkan karakter disiplin kepada peserta didik yaitu salah satunya dengan membuat atau merancang RPP yang sesuai dengan kondisi yang nanti akan menjadi acuan agar pembelajaran lebih terarah dengan efektif dan efesien. RPP harus disiapkan oleh guru sebelum kegiatan pembelajaran dilaksanakan. Sesuai dengan hal diatas, didukung oleh pemaparan menurut Mulyasa (2009: 183) mengungkapkan bahwa RPP adalah rencana penggambaran prosedur dan manajemen pengajaran untuk mencapai satu atau lebih kompetensi dasar yang ditetapkan yang ditetapkan dalam standar kompetensi dan dijabarkan dalam silabus.

Terdapat 5 komponen penting dalam pembuatan RPP, yaitu (tujuan pembelajaran, langkah kegiatan pembelajaran, materi pembelajaran, metode dan penilaian) berikut juga penguatan karakter dalam pembelajaran seperti disiplin, tanggung jawab serta kebersamaan. Dalam pembuatan RPP, guru membuatnya secara bebas untuk mengembangkannnya sesuai dengan strategi yang akan di terapkan nanti tanpa adanya standar yang baku. Dan pembuatan RPP biasanya diketik agar format penulisan menjadi lebih rapih dan mudah untuk dilihat.

Setelah memaparkan hasil wawancara yang dilakukan oleh peneliti dari narasumber maka dapat dikatakan bahwa persiapan RPP untuk menanamkan karakter disiplin pada peserta didik selalu guru lakukan.

\section{Mempersiapkan Materi yang akan Diajarkan}

Dalam upaya mananamkan karakter disiplin pada peserta didik, penting untuk guru mempersiapkan materi yang akan diajarkan kepada peserta didik. Diantaranya guru harus mempelajari materi yang akan diajarkannya terlebih dahulu sekaligus alat peraga atau media pembelajaran yang sesuai dengan materi yang dibawakan. Di dalam materi pembelajaran di jabarkan oleh guru tetapi hanya intinya saja. Di kurikulum saat ini, guru terkadang mendapat kesulitan bila materi yang diajarkan tidak berkaitan sehingga sulit untuk menjelaskannya kepada peserta didik.

Undang-Undang Nomor 14 tahun 2005 Tentang Guru dan Dosen menyatakan bahwa guru adalah pendidik profesional dengan tugas utama mendidik, mengajar, membimbing, mengarahkan, melatih, menilai, 
dan mengevaluasi peserta didik pada pendidikan anak usia dini jalur pendidikan formal, pendidikan dasar, dan pendidikan menengah. Undang-undang tersebut mengisyaratkan bahwa guru harus memiliki kualifikasi dalam mempersiapkan perlengkapan sebuah proses pembelajaran, di antarnya sebuah Rencana Pelaksanaan Pembelajaran (RPP).

Setelah memaparkan hasil wawancara yang dilakukan oleh peneliti dari narasumber maka dapat dikatakan bahwa dalam mempersiapkan materi yang akan diajarkan untuk menanamkan karakter disiplin pada peserta didik sudah guru laksanakan.

\section{Mempersiapkan metode dan strategi dalam menanamkan karakter disiplin}

Kemudian mempersiapkan metode dan strategi juga merupakan bentuk kinerja guru dalam menanamkan karakter disiplin terhadap peserta didik. Seperti yang dipaparkan oleh Oemar (2003) Metode pembelajaran merupakan salah satu cara yang digunakan oleh guru dalam mengadakan hubungan dengan peserta didik pada saat berlangsungnya pembelajaran untuk mencapai tujuan pembelajaran yang ditetapkan. Metode yang sering digunakan guru dalam kegiatan pembelajaran terhadap peserta didik yaitu, ceramah, diskusi, bermain peran, demostrasi, tanya jawab dsb.

Salah satu metode pembelajaran yang dapat menanamkan karakter disiplin yang kuat adalah dengan diskusi yang sesuai dengan aturan. Tetapi semua metode pembelajaran mengandung karakter disiplin didalamnya. Adapun strategi-strategi yang digunakan dalam pembelajaran seperti, Inquiri, CTL, partisipatif, dan disesuaikan dengan tujuan pembelajaran. Dan strategi yang digunakan terkadang berbeda-beda menyesuaikan dengan kondisi.

Setelah memaparkan hasil wawancara yang dilakukan oleh peneliti dari narasumber maka dapat dikatakan bahwa mempersiapkan metode dan strategi pembelajaran untuk menanamkan karakter disiplin pada peserta didik selalu guru laksanakan.

\section{Mempersiapkan format penilaian dan evaluasi}

Mempersiapkan format penilaian dan evaluasi penting dalam menanamkan karakter disiplin kepada peserta didik. Diawali dengan guru membuat format penilaian terlebih dahulu dan format penilaian yang dibuat meliputi penilaian pengetahuan, sikap dan keterampilan peserta didik. Bila terdapat peserta didik yang memiliki nilai dibawah rata-rata, guru biasanya memberikan remedial dan kembali menjelaskan kepada materi yang belum dipahami oleh peserta didik. Evaluasi dilakukan biasanya secara tulisan maupun lisan. Seperti yang di paparkan oleh (Mahirah: 2017) menurut beliau evaluasi secara umum dapat diartikan sebagai proses sistematis untuk menentukan nilai sesuatu (ketentuan, kegiatan, keputusan, unjuk-kerja, proses, orang, objek dan yang lainnya) berdasarkan kriteria tertentu melalui penilaian Setelah memaparkan hasil wawancara yang dilakukan oleh peneliti dari narasumber maka dapat dikatakan bahwa mempersiapkan format penilaian dan evaluasi untuk menanamkan karakter disiplin pada peserta didik selalu guru laksanakan.

\section{Proses Pelaksanaan Penanama Karakter Disipin Pada Peserta Didik Kelas 4}

Menanamkan karakter disiplin kepada peserta didik adalah tugas guru pada saat kegiatan pembelajaran disekolah. Apabila peserta didik tidak memiliki karakter disiplin maka akan berdampak kedepannya seperti datang tidak tepat waktu, membuang sampah sembarangan, dsb. Hal ini diperkuat oleh Liang Gie (1972) dalam Husdarta 2010: 110), menurutnya disiplin adalah suatu keadaan tertib dimana orang-orang yang bergabung dalam suatu organisasi tunduk pada peraturanperaturan yang telah ada dengan rasa senang. Selama peneliti melakukan pengamatan peneliti mengamati kinerja guru dalam menanamkan karakter disiplin kepada peserta didik. Pertama guru terlihat datang ke sekolah tepat waktu dan menyambut peserta didik yang datang ke sekolah. Terlihat beberapa peserta didik datang terlambat dan guru memberikan hukuman dan meminta peserta didik untuk 
datang tepat waktu. Guru pun memasuki kelas ketika bel masuk telah berbunyi dan meminta peserta didik untuk masuk kedalam kelas untuk kegiatan pembelajaran. Ketika waktu ibadah telah tiba, guru mengajak peserta didik untuk beribadah tepat waktu.

Hasil pengamatan yang telah dilakukan peneliti peserta didik sangat mematuhi peraturan masuk ke sekolah dengan tepat waktu karena apabila datang terlambat akan diberikan hukuman oleh guru dan diberi nasehat agar datang kesekolah tepat waktu. Adapun hukuman yang diberikan bermacammacam seperti hanya diberi nasehat, lalu tidak diizinkan untuk masuk sekolah dan dipersilahkan untuk pulang kerumahnya kembali. Guru dan peserta didik memasuki kelas dengan tertib ketika bel masuk sudah berbunyi dan siap mengikuti pembelajaran.

\section{Penguatan karakter disiplin saat berpakaian}

Kemudian penguatan karakter disiplin dalam berpakaian, disini peneliti mengamati yang pertama guru berpakaian rapih dan sopan sesuai dengan jadwal yang ditetapkan sekolah. Dan guru mengingatkan apabila ada peserta didik yang sengaja atau tidak memakai seragam yang tidak sesuai dengan jadwal. Hal tersebut diperkuat oleh pemaparan (Trisnawan: 2017:31) menurut beliau pemakaian seragam sekolah kepada peserta didik bertujuan agar peserta didik mudah diarahkan, diatur agar peserta didik berdisiplin diri. Seragam sekolah berarti pakaian yang sama potongan dan warnanya yang digunakan untuk melakukan kegiatan sekolah.

Hasil pengamatan yang telah dilakukan peneliti guru terlihat berpakaian rapih dan sopan mengikuti peraturan yang ada dan berseragam sesuai dengan jadwal harian yang telah ditetapkan sekolah. Kemudian apabila ada peserta didik yang tidak berpakaian sesuai jadwal atau tidak rapih dan sopan maka guru akan menegur dan meminta peserta didik tersebut untuk pulang mengganti pakaiannnya dan merapihkan pakaiannya apabila peserta didik berpakaian tidak rapih dan sopan.

\section{Penguatan karakter disiplin belajar peserta didik}

Pada penguatan karakter disiplin belajar peserta didik disini setelah peneliti melakukan pengamatan yang pertama adalah ketika dalam pembelajaran berlangsung guru meminta peserta didik untuk tidak berisik saat penyampaian materi dan pada saat ujian guru meminta peserta didik agar tidak mencontek tugas yang telah diberikan kepada temannya dan mengumpulkan tugas dengan tepat waktu. Seperti yang dipaparkan oleh Prijodarminto yang dikutip oleh Tu'u (2017: 31) mengungkapkan bahwa disiplin belajar adalah suatu kondisi yang tercipta dan terbentuk melalui proses belajar peserta didik dari serangkaian perilaku yang menunjukkan nilainilai ketaatan, kepatuhan, kesetiaan, keteraturan dan atau ketertiban.

Hasil pengamatan yang telah dilakukan peneliti, peserta didik terlihat mengikuti pembelajaran dengan tertib saat guru telah meminta peserta didik agar untuk tidak berisik selama penyampaian materi. Dan ketika pada saat diberikan tugas, guru meminta agar peserta didik untuk tidak mencontek tugas milik temannya dan meminta untuk mengumpulkan tugas dengan tepat waktu sesuai dengan waktu pengumpulan yang telah ditentukan.

\section{Penguatan karakter disiplin pada peraturan}

Kemudian penguatan karakter disiplin pada peraturan peserta didik setelah peneliti melakukan pengamatan yaitu diawali dengan pada saat akan memasuki kelas guru memberikan peringatan kepada peserta didik yang tidak lengkap memakai atribut karena banyak sekali peserta didik yang tidak suka memakai sabuk. Kemudian guru mengingatkan peserta didik untuk membuang sampah pada tempatnya dan melaksanakan piket harian yang sudah dijadwalkan. Dan pada saat masuk kelas, peserta didik diminta untuk melepas sepatu sebelum memasuki ruang kelas. Disiplin sebagai kondisi yang tercipta dan terbentuk melalui proses dari serangkaian perilaku yang menunjukan nilai-nilai ketaatan, kepatuhan, kesetiaan, keteraturan atau 
ketertiban. Nilai-nilai tersebut telah menjadi bagian perilaku dalam kehidupannya. Perilaku itu tercipta melalui proses binaan melalui keluarga, pendidikan, dan pengalaman (Prijodarminto dalam Tu'u 2017: 31).

Hasil pengamatan yang telah dilakukan peneliti, terlihat guru menegur peserta didik yang tidak lengkap memakai atribut, dan mengingatkan peserta didik untuk tidak membuang sampah pada tempatnya. Peserta didik diminta untuk piket sesuai dengan jadwal yang telah dibuat dan melepas sepatu pada saat memasuki ruang kelas.

\section{Hasil dari Penanaman Karakter Disiplin pada Peserta Didik}

Pengertian karakter disiplin menurut Kemendiknas (2010:9), disiplin adalah tindakan yang menunjukan perilaku tertib dan patuh pada berbagai ketentuan dan peraturan. Hasil penelitian menunjukan bahwa hasil kinerja guru dalam menanamkan karakter disiplin terhadap peserta didik kelas 4 di SDN Banjarsari 5 menunjukan beberapa dampak positif, karena dilihat dari hasil pengamatan yang peneliti lakukan tentang kinerja guru dalam menanamkan karakter disiplin, menanamkan karakter disiplin perlu ditanamkan dan ditumbuhkan sejak dini, karena karakter disiplin merupakan modal utama dalam bersikap dan menghargai dimanapun dan kapanpun peserta didik berada. Indikator dari nilai disiplin ialah sebagai berikut: (a) membiasakan hadir tepat waktu, b) membiasakan mematuhi aturan, c) menggunakan pakaian sesuai dengan ketentuan (Kemendiknas 2010: 26).

Dampak positif menanamkan karakter disiplin dari hasil pengamatan peneliti yaitu peserta didik menjadi memilki karakter disiplin yang lebih baik. Saat peneliti melakukan pengamatan seperti kedisiplinan dalam hal waktu, peserta didik datang ke sekolah dengan tepat waktu dan takut apabila terlambat maka tidak diizinkan masuk dan jika melakukan kesalahannya lagi maka guru akan meminta orang tua peserta didik untuk menjemputnya disekolah dan diperintahkan untuk kembali pulang dan belajar dirumah. Kemudian pada saat pembelajaran peserta didik mengumpulkan tugas yang sudah diberikan aturan waktu, apabila ada yang tidak mengumpulkan tugas atau terlambat maka terlihat guru tidak menerima tugas tersebut dan memberikan nasehat agar mengumpulkan tugas yang diberikan dengan tepat waktu. Kemudian peserta didik terlihat beribadah tepat waktu ketika waktu ibadah telah tiba.

Kemudian kedisiplinan dalam hal berpakaian, berdasarkan hasil pengamatan peneliti terlihat peserta didik mentaati dan memakai pakaian sesuai jadwal yang telah ditentukan dengan rapih dan sopan. Terlihat juga guru memberikan peringatan kepada peserta didik yang tidak memakai seragam sesuai jadwal dan disuruh pulang untuk menggantinya. Dalam hal ini maka kedisiplinan peserta didik dalam hal berpakaian sudah baik.

Lalu pada kedisiplinan belajar peserta didik, berdasarkan pengamatan peneliti terlihat dalam kegiata pembelajaran suasana belajar cukup tertib tidak ada peserta didik yang membuat gaduh atau berisik dan juga tidak ada peserta didik yang boleh keluar masuk kelas tanpa izin guru. Kemudian terlihat guru memakai strategi yang sesuai dengan tujuan dalam pembelajaran agar semakin efektif dan efesien. Dalam suasana pembelajaran, masih terdapat peserta didik yang berisik namun hanya sedikit sehingga tidak menggangu penyampaian materi. Dan ketika ujian, terlihat peserta didik mengerjakan dengan tertib dan guru menghimbau peserta didik untuk tidak mencontek apabila mencontek akan disuruh mengerjakan di dekat guru seperti yang dilakukan ibu Eva. Dalam hal ini maka kedisiplinan belajar peserta didik sudah cukup baik.

Kemudian peserta didik dalam mentaati peraturan dan tata tertib disekolah, berdasarkan pengamatan yang dilakukan peneliti terlihat peserta didik tidak ada yang berkelahi, tidak makan di dalam kelas, berbicara dengan guru, teman dan kepala sekolah dengan sopan dan membuang sampah pada tempatnya. Lalu terlihat guru juga menegur peserta didik apabila ada yang 


\section{PRIMARY: JURNAL PENDIDIKAN GURU SEKOLAH DASAR \\ VOLUME 10 NOMOR 4 AGUSTUS 2021}

ISSN : 2303-1514 | E-ISSN : 2598-5949

DOI : http://dx.doi.org/10.33578/jpfkip.v10i4.8139

https://primary.ejournal.unri.ac.id/index.php/JPFKIP

melanggar peraturan dan tata tertib sekolah dan akan dikenakan hukuman bila peserta didik tersebut melanggar lagi. Adapun pelanggaran yang kadang terlihat dan tidak mengerjakan PR dan pada saat jadwal piket. Dari penjelasan diatas maka peserta didik sudah mentaati peraturan dan tata tertib di sekolah.

\section{DAFTAR PUSTAKA}

Husdarta. (2010). Psikologi Olahraga. Bandung: Alfabeta

Kementrian Pendidikan Nasional. (2010). Pengembangan Pendidikan Budaya dan Karakter Bangsa. Jakarta: Kementrian Pendidikan Nasional.

Mahirah, B. (2017). Evaluasi Belajar Peserta Didik. Jurnal Idaarah, vol 1 no 2.

Mulyasa, E. (2009). Menjadi Guru Profesional Menciptakan Pembelajaran Kreatif dan Menyenangkan. Bandung: PT Remaja Rosdakarya.

Samani, M \& Hariyanto (2016). Pendidikan Karakter. Bandung: PT Remaja Rosdakarya.

Saondi, O., \& Suherman, A. (2012). Etika Profesi Keguruan. Bandung: PT Refika Aditama.

Sugiono. (2014). Metode Penelitian Kualitatif dan $R$ and D. Bandung: Penerbit Alfabeta

Tulus, T. (2017). Peran Disiplin pada Perilaku dan Prestasi Siswa. Jakarta: PT. Grasindo

Undang-Undang RI Nomor. 14. (2005). Guru dan Dosen. Jakarta: Depdiknas.
Yaumi, M. (2014). Pendidikan Karakter Landasan. Jakarta: Prenada Media 